\title{
$17 \beta$-Estradiol induces protein thiol/disulfide oxidoreductases and protects cultured bovine aortic endothelial cells from oxidative stress
}

\author{
Kuniaki Ejima $^{1,2}$, Hiroki Nanri ${ }^{1}$, Masaru Araki ${ }^{1}$, Koji Uchida $^{3}$, Masamichi Kashimura ${ }^{2}$ and Masaharu Ikeda ${ }^{1}$ \\ ${ }^{1}$ Department of Health Development and ${ }^{2}$ Department of Obstetrics and Gynecology, University of Occupational and Environmental Health, Kitakyushu \\ 807-8555, Japan and ${ }^{3}$ the Laboratory of Food and Biodynamics, Nagoya University School of Agriculture, Nagoya, Japan
}

(Correspondence should be addressed to H Nanri, Health Development, Institute of Industrial and Ecological Science, University of Occupational and Environmental Health, Iseigaoka 1-1, Yahatanishi-ku, Kitakyushu, 807-8555, Japan)

\begin{abstract}
Objective: To examine whether or not estrogens induced the expression of protein thiol/disulfide oxidoreductases such as protein disulfide isomerase (PDI), thioredoxin (Trx), Trx reductase, and glutaredoxin (Grx) in vascular endothelial cells.

Methods: The regenerative effects of the protein thiol/disulfide oxidoreductases, PDI, Trx and Grx, on oxidatively damaged proteins were assayed using $\mathrm{H}_{2} \mathrm{O}_{2}$-inactivated glyceraldehyde-3-phosphate dehydrogenase (GAPDH) as a reporter enzyme. The induction of protein thiol/disulfide oxidoreductases and the accumulation of protein adducts generated by lipid peroxidation were examined by Western blotting in estrogen-treated bovine aortic endothelial cells (BAECs).

Results: Reduced PDI, Trx and Grx regenerated the $\mathrm{H}_{2} \mathrm{O}_{2}$-inactivated GAPDH in vitro. The levels of these protein disulfide oxidoreductases in BAECs were increased by pretreatment with $0.01-10 \mu \mathrm{mol} / \mathrm{l}$ $17 \beta$-estradiol, the largest increase (about fourfold of the control) being found for PDI. Other sex hormones such as progesterone and testosterone did not affect the contents of these oxidoreductases in BAECs. 4-Hydroxy-2-nonenal (HNE)-protein adducts, which are generated by lipid peroxidation, were accumulated in BAECs exposed to paraquat, whereas the pretreatment of BAECs with $17 \beta$-estradiol suppressed their accumulation.

Conclusions: The estrogen-mediated induction of the protein thiol/disulfide oxidoreductases such as PDI, Trx, Trx reductase and Grx suggested a possible involvement of these oxidoreductases in the antioxidant protection of estrogen observed in the vascular system.
\end{abstract}

European Journal of Endocrinology 140 608-613

\section{Introduction}

Epidemiological studies have indicated a close relationship between menopause and an increase in the incidence of cardiovascular disease in women, suggesting that female hormones have strong effects in maintaining the integrity of vascular walls (1-3). Indeed, a number of studies have documented that estrogen has various beneficial effects on the vascular system. Some of the effects of estrogen have been shown to be associated with protection against oxidative injury to blood vessels (4), but the detailed mechanism of the cardiovascular protection mediated by estrogen still remains unknown.

We have reported that thioredoxin (Trx) and glutaredoxin (Grx) serve as a repair system for oxidatively damaged proteins via reduction of oxidized thiols in vascular endothelial cells (5-7). Furthermore, recent studies have shown that Trx and Trx reductase can also scavenge reactive oxygen species $(8-11)$, indicating that these proteins constitute a novel cellular defense system against oxidative injury in addition to the conventional antioxidant enzymes such as catalase, superoxide dismutase and glutathione peroxidase.

Growing evidence shows that estrogens have direct antioxidant activities to protect various tissues from oxidative damage (4), but the effects of estrogens on the antioxidant enzymes, particularly on the protein thiol/disulfide oxidoreductases, have not been well investigated. In the present study, we examined whether or not the effects of estrogens on the cardiovascular system were associated with the induction of these protein thiol/disulfide oxidoreductases. The results obtained from vascular endothelial cells as target tissues demonstrated that estrogen increased the protein levels of protein disulfide isomerase (PDI), Trx, Trx reductase and Grx, suggesting a possible involvement of these protein thiol/disulfide oxidoreductases in estrogen-mediated antioxidant defense in the cardiovascular system. 


\section{Materials and methods}

\section{Materials}

Rabbit muscle glyceraldehyde-3-phosphate dehydrogenase (GAPDH) was from Boehringer-Mannheim (Mannheim, Germany). Progesterone, $17 \beta$-estradiol and testosterone were purchased from Sigma (St. Louis, MO, USA). Hormone stock solutions of $15 \mathrm{mg} / \mathrm{ml}$ were made with $100 \%$ ethanol as solvent. A final ethanol concentration of $0.04 \%$ did not affect cell morphology or viability of the cells in our experiments. Antibody against 4-hydroxy-2-nonenal (HNE)-protein adducts was prepared as described elsewhere (12). Antisera raised against PDI, Trx, Grx, and Trx reductase were prepared by immunizing albino rabbits with each of the purified proteins $(5-7)$.

\section{Cell culture}

Bovine aortic endothelial cells (BAECs) were harvested from bovine thoracic aorta and cultured in RPMI 1640 medium supplemented with $10 \%$ fetal calf serum as described by Kitazono et al. (13). Endothelial cells at up to passage 20 were used for the experiments. The number of living BAECs was estimated from cell associated lactate dehydrogenase activity. The protein content of the cell lysate was determined using the Bio-Rad (Hercules, CA, USA) protein assay kit, with bovine serum albumin as standard.

\section{Regeneration of $\mathrm{H}_{2} \mathrm{O}_{2}$-inactivated GAPDH by purified PDI, Trx, and Grx}

Trx, Trx reductase, Grx and PDI were purified from bovine liver or heart as described elsewhere $(5,6,14)$. Reduced Trx, PDI and Grx were freshly prepared by reduction with $2 \mathrm{mmol} / \mathrm{l}$ dithiothreitol (5). We used GAPDH, which has critical cysteines susceptible to oxidative damage, as a reporter enzyme for the regeneration reaction. GAPDH $(3.4 \mu \mathrm{mol} / \mathrm{l})$ was treated with $0.3 \mathrm{mM} \mathrm{H}_{2} \mathrm{O}_{2}$ for $5 \mathrm{~min}$ at $25^{\circ} \mathrm{C}$ and $30 \mu \mathrm{g} / \mathrm{ml}$ catalase was then added to eliminate the $\mathrm{H}_{2} \mathrm{O}_{2}$. Regeneration of the $\mathrm{H}_{2} \mathrm{O}_{2}$-inactivated GAPDH $(1.7 \mu \mathrm{mol} / \mathrm{l})$ by reduced or oxidized forms of PDI $(5 \mu \mathrm{mol} / \mathrm{l})$, Trx $(4 \mu \mathrm{mol} / \mathrm{l})$, and Grx $(4 \mu \mathrm{mol} / \mathrm{l})$ was carried out at $37^{\circ} \mathrm{C}$ in $100 \mathrm{mmol} / \mathrm{l}$ triethanolamine (pH 7.6) as described previously $(5,6)$. After the indicated periods of incubation, GAPDH activity was assayed and expressed as a percentage of that of the untreated enzyme.

\section{Western blotting analysis of protein thiol/oxidoreductases}

BAECs were pretreated in the presence or absence of sex hormones for $24 \mathrm{~h}$ at $37^{\circ} \mathrm{C}$ in a $5 \% \mathrm{CO}_{2}$ atmosphere. The final concentration of the hormones (17 $\beta$-estradiol, progesterone, testosterone) and tamoxifen (an estrogen

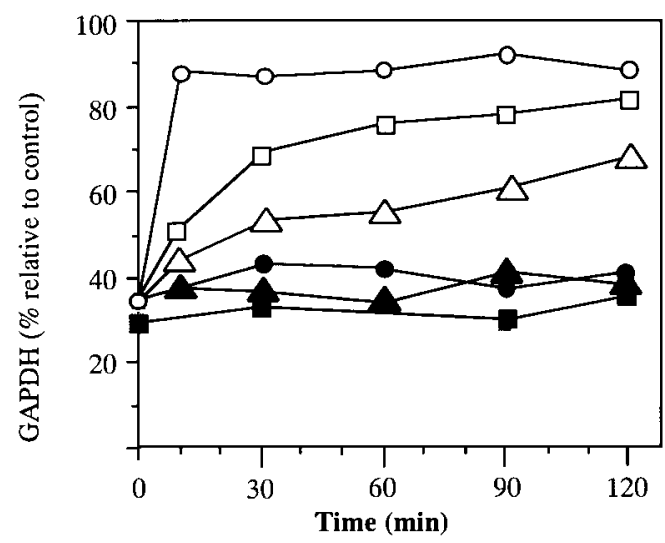

Figure 1 Regeneration of $\mathrm{H}_{2} \mathrm{O}_{2}$-inactivated GAPDH $(1.7 \mu \mathrm{mol} / \mathrm{l})$ by reduced or oxidized PDI, Trx, and Grx was carried out at $37^{\circ} \mathrm{C}$ in $100 \mu \mathrm{mol} / /$ triethanolamine $(\mathrm{pH} 7.6)$ as described in Methods. After the indicated periods of incubation, GAPDH activity was assayed and expressed as the percentage of that of the untreated enzyme. $\bigcirc$, Reduced Trx; $\square$, reduced PDI; $\triangle$, reduced Grx; $\bullet$, oxidized Trx; $\mathbf{\square}$, oxidized PDI; $\boldsymbol{\Delta}$, oxidized Grx. Each point represents the average of the two single determinations from two independent experiments.

receptor inhibitor) ranged from 0.01 to $10 \mu \mathrm{mol} / \mathrm{l}$. After exposure to the hormones, the cells were lysed with buffer A containing $5 \mathrm{mmol} / \mathrm{l}$ Hepes (pH 7.4), 1 mmol/l EDTA, $0.2 \%$ Triton X-100, and protease inhibitors (chymostatin $5 \mu \mathrm{g} / \mathrm{ml}$, leupeptin $10 \mu \mathrm{g} / \mathrm{ml}$, antipain $10 \mu \mathrm{g} / \mathrm{ml}$, pepstatin $10 \mu \mathrm{g} / \mathrm{ml}$, and $p$-amidino phenylmethylsulfonyl fluoride $5 \mu \mathrm{g} / \mathrm{ml}$ ), and centrifuged at 10000 r.p.m. for $10 \mathrm{~min}$. An equal amount of protein in the supernatant was separated by SDS-PAGE, transferred onto Imobilon-P membrane (Millipore, Bedford, MA, USA) and probed with polyclonal rabbit antibodies raised to PDI, Trx, Grx, and Trx reductase. An enhanced chemiluminescence detection kit (Amersham, Little Chalfont, UK) was used to visualize the protein bands. Densitometric analysis of the immunoblots was performed using a public-domain computer program NIH Image (Wayne Rasband, NIH, Bethesda, MD, USA).

\section{Effect of $17 \beta$-estradiol on accumulation of HNE-modified proteins}

We examined the effect of $17 \beta$-estradiol on paraquatmediated lipid peroxidation (15) in BAECs. After pretreatment with or without $17 \beta$-estradiol $(10 \mu \mathrm{mol} / \mathrm{l})$ for $24 \mathrm{~h}$, the monolayers of BAEC were thoroughly washed and further incubated with paraquat (100$500 \mu \mathrm{mol} / \mathrm{l}$ ) for $24 \mathrm{~h}$. The accumulation of HNE-modified proteins in BAECs was determined by Western blot analysis of the cell lysate using anti-HNE antibody.

\section{Statistical analysis}

Data for the expression of protein thiol/disulfide oxidoreductases were expressed as means \pm S.D. from 
at least three independent experiments. Statistical comparison was performed by Student's $t$-test. Differences were considered statistically significant at $P<0.05$.

\section{Results}

GAPDH, which has critical cysteines susceptible to oxidative damage, was used as a reporter enzyme for the regeneration reaction. A brief exposure of GAPDH to $0.3 \mathrm{mmol} / \mathrm{l} \mathrm{H}_{2} \mathrm{O}_{2}$ caused an approximately $70 \%$ decrease in its activity. Incubation of the inactivated GAPDH with reduced Trx, PDI, and Grx restored the GAPDH activity to $65-90 \%$ of the control, whereas incubation with the oxidized enzymes failed to regenerate the inactivated GAPDH (Fig. 1), indicating that only the reduced forms of the protein disulfide oxidoreductases exerted regenerative effects on the $\mathrm{H}_{2} \mathrm{O}_{2}$-inactivated enzymes.

We examined the effect of $17 \beta$-estradiol on the levels of the protein thiol/disulfide oxidoreductases in BAECs by Western blotting analysis. The pretreatment of BAEC with $17 \beta$-estradiol increased the levels of all these protein thiol/disulfide oxidoreductases in a concentration-dependent manner, with the maximal increases in PDI, Trx, Grx and Trx reductase being about 4.0-, 2.2-, 1.7- and 1.5-fold of the control, respectively (Figs. 2 and 3). Tamoxifen, a specific
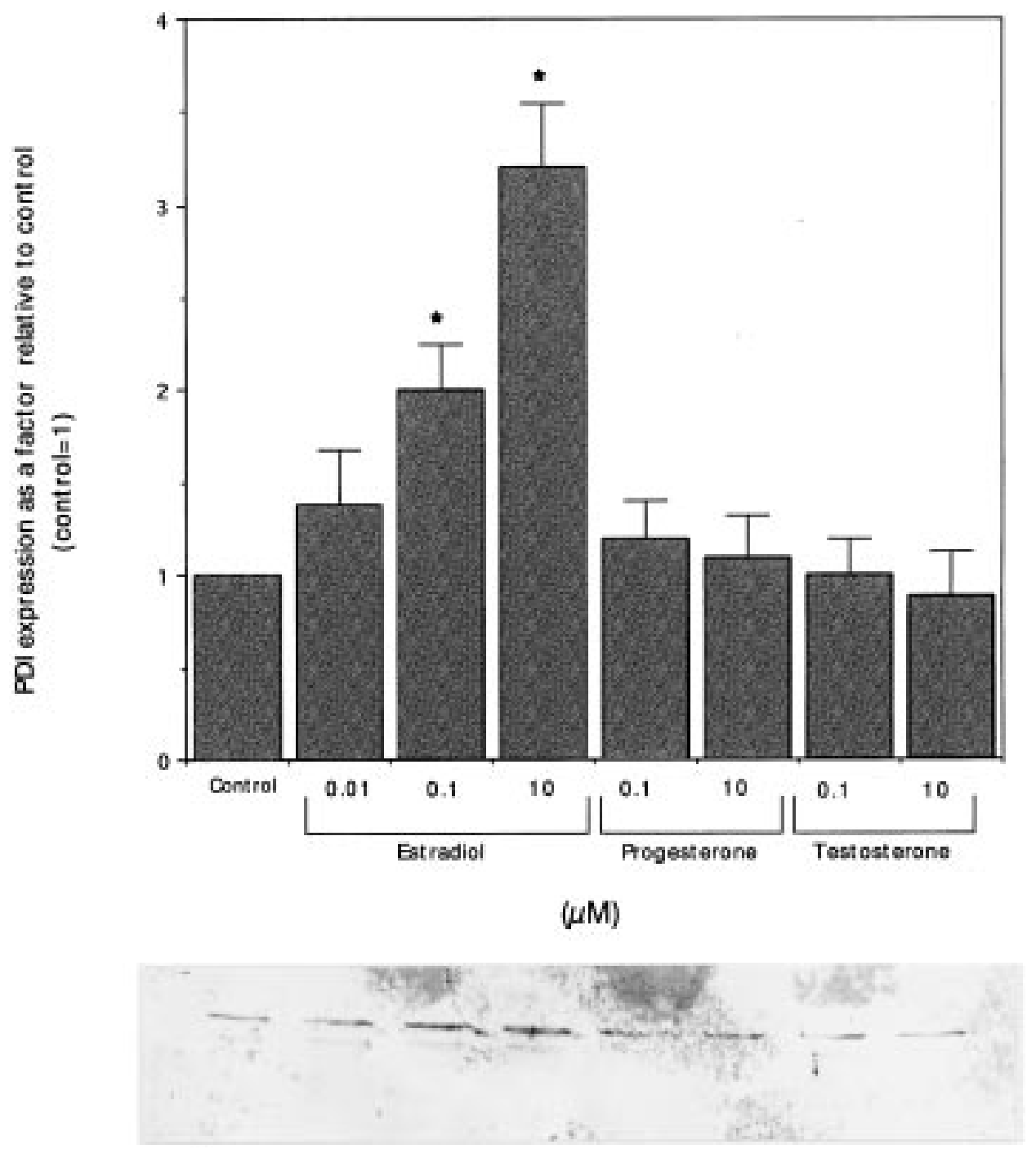

Figure 2 Enhancement of the protein level of PDI in BAECs upon treatment with $17 \beta$-estradiol. Cells were incubated for $24 \mathrm{~h}$ in the absence (control) or presence of $0.01-10 \mathrm{mmol} / 17 \beta$-estradiol, progesterone or testosterone. The protein level of PDI was determined by Western blotting analysis as described in Methods. The results of densitometric analysis from three independent experiments were expressed as ratios relative to control and presented as means \pm S.D. ${ }^{*}$ Significant in comparison with control $(P<0.05)$. Representative Western blotting data are shown below the histogram. 

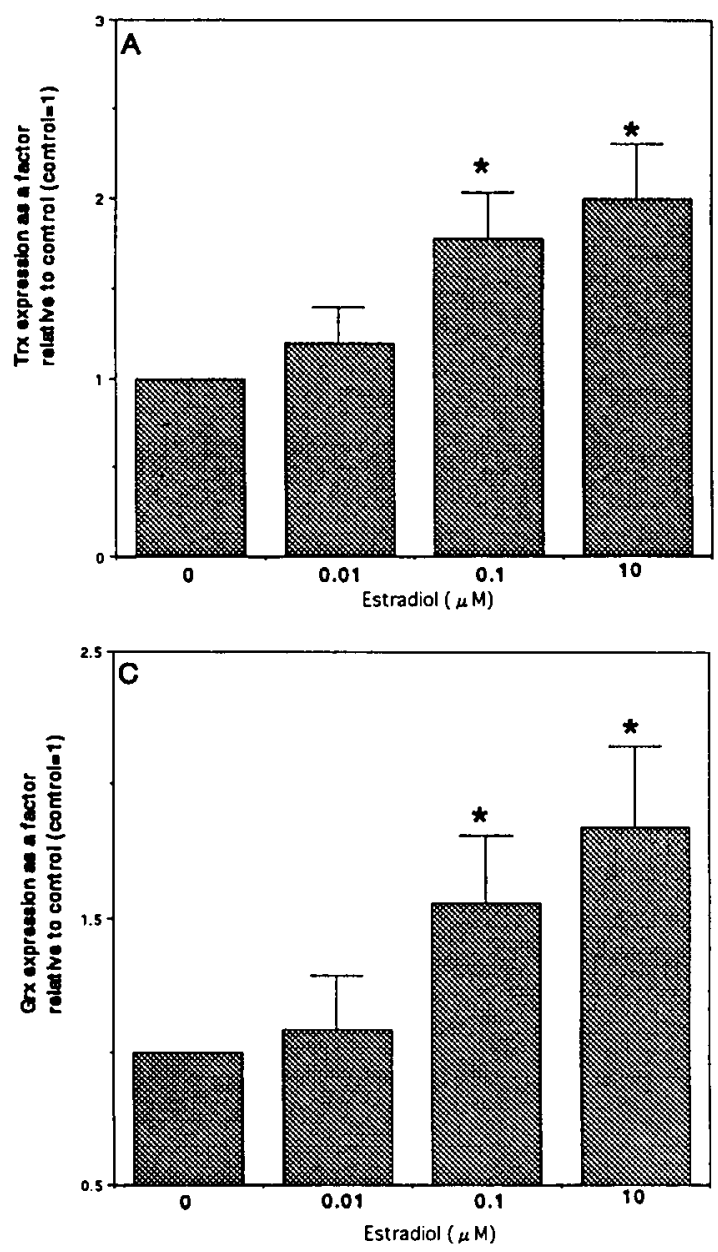

antagonist of estrogen receptor (16), inhibited the induction of Trx, Grx and Trx reductase, but not that of PDI (data not shown), suggesting that the regulatory pathway of the estrogen-mediated induction of PDI may be different from that of the other members of the protein thiol/disulfide oxidoreductases. Pretreatment of BAECs with progesterone and testosterone did not affect the protein levels of PDI (Fig. 2) or the other protein thiol/disulfide oxidoreductases (data not shown).

Estrogen has been reported to have direct antioxidant effects against oxidative stress in various tissues, either in vitro or in vivo (17-20). We therefore examined whether or not estrogens protected BAECs from oxidative stress, using an experimental model of paraquat-mediated lipid peroxidation (15). As shown in Fig. 4, the accumulation of HNE-modified proteins in BAECs exposed to $100-500 \mu \mathrm{mol} / \mathrm{l}$ paraquat was increased in a dose-dependent manner, whereas preteatment of BAECs with $17 \beta$-estradiol, which caused several-fold increases in the levels of the protein thiol/disulfide oxidoreductases, markedly inhibited the accumulation of HNE-modified proteins.

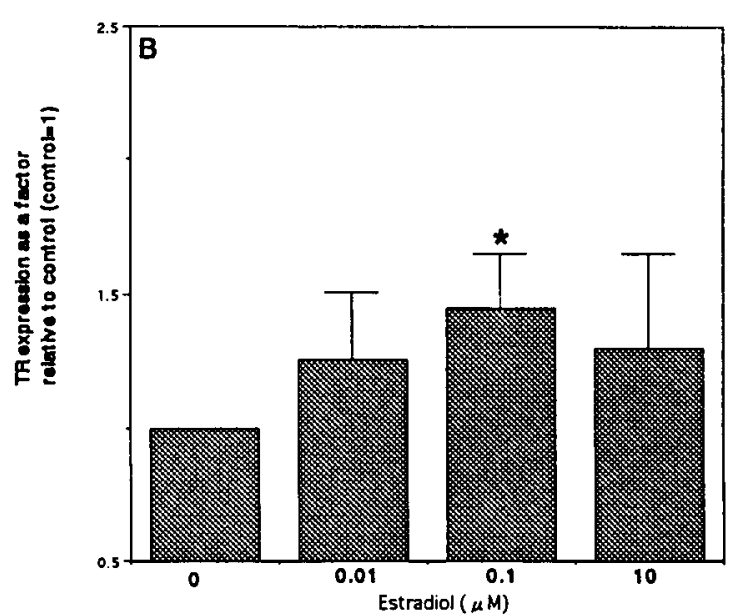

Figure 3 Enhancement of the protein levels of (A) Trx, (B) Trx reductase, and (C) Grx in BAECs upon treatment with $17 \beta$-estradiol, determined by Western blotting analysis. Cells were incubated for $24 \mathrm{~h}$ in the absence (control) or presence of $0.01-10 \mu \mathrm{mol} / \mathrm{l} 17 \beta$ estradiol. The results of densitometric analysis from three independent experiments were expressed as ratios relative to control and presented as means \pm S.D. *Significant in comparison with control $(P<0.05)$.

\section{Discussion}

We have shown that Trx and Grx have a thioldependent regeneration action on oxidatively damaged proteins $(5,6)$. In the present study, we found that PDI also exhibited a similar regeneration activity, with a potency comparable to that of these enzymes. This finding suggests that the members of the protein thiol/ disulfide oxidoreductases that have different subcellular localizations and different electron donors may serve as redundant repair systems for oxidatively damaged proteins.

The evidence demonstrating the effect of estrogens on the expression of antioxidant enzymes is very limited. Oberley et al. (21) have shown that exposure to diethylstilbestrol, a synthetic estrogen, increases manganese superoxide dismutase activity in normal hamster kidney proximal tubules, but the effects of estrogens on the expression of other antioxidant enzymes such as catalase and glutathione peroxidase have not been demonstrated experimentally. In the present study, we showed that the pretreatment of 


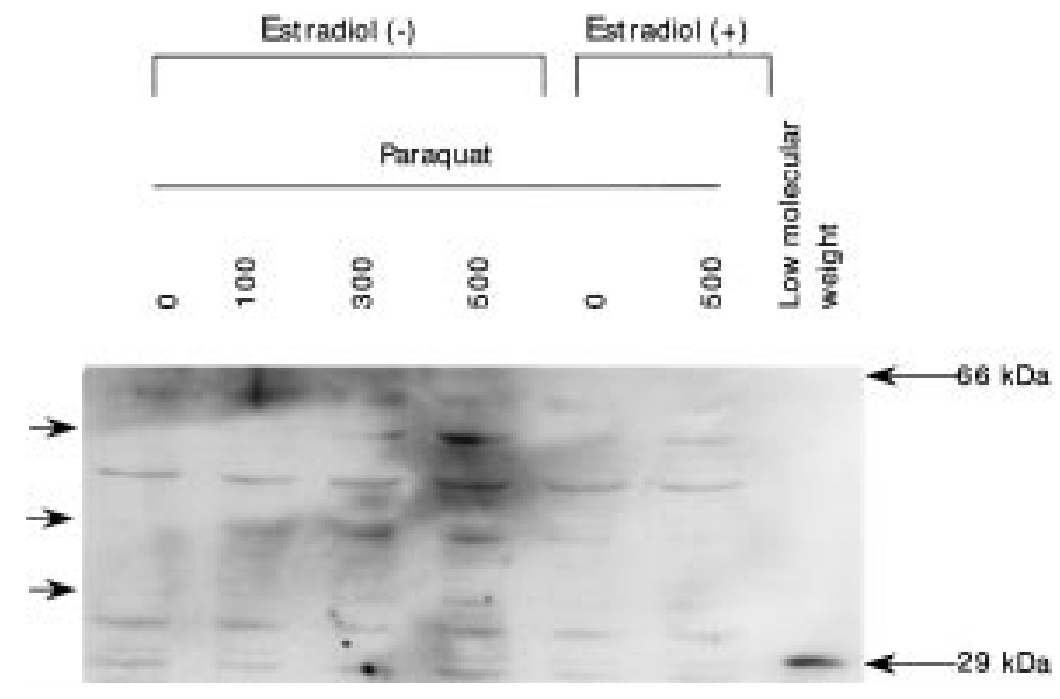

Figure 4 Accumulation of HNE-modified proteins in BAECs exposed to $100-500 \mu \mathrm{mol} / \mathrm{l}$ paraquat, and the protective effect of $17 \beta$ estradiol. Cells were incubated for $24 \mathrm{~h}$ in the absence $(-$, control) or presence $(+)$ of $17 \beta$-estradiol, thoroughly washed and exposed to $100-500 \mu \mathrm{mol} / /$ paraquat for $24 \mathrm{~h}$. HNE accumulation was determined by Western blotting analysis. Arrows at the left indicate the enhanced HNE-modified proteins.
BAECs with $17 \beta$-estradiol induced the expression of the protein thiol/disulfide oxidoreductases, a novel antioxidant system recognized recently. As the protein thiol/ disulfide oxidoreductases repair oxidatively damaged proteins (5-7) and eliminate reactive oxygen species $(8-11)$, the present results suggested a potential mechanism of the estrogen-mediated antioxidant functions that occur in the cardiovascular system.

The estradiol concentrations $(0.01-10 \mu \mathrm{mol} / \mathrm{l})$ used in these experiments were higher than those observed in non-pregnant females $(0.01-1.0 \mathrm{nmol} / \mathrm{l})$. In certain conditions, particularly during pregnancy, however, comparable concentrations $(0.01-0.1 \mu \mathrm{mol} / \mathrm{l})$ of $17 \beta$ estradiol are observed (22). As shown in Figs 2 and 3, the effect of estradiol was evident even at $0.01 \mu \mathrm{mol} / \mathrm{l}$, suggesting that the estrogen-mediated induction of the protein thiol/disulfide oxidoreductases may occur in vivo. In fact, the expression of Trx mRNA has been reported to be enhanced in late pregnancy (23).

The expression of Trx and PDI is known to be induced by various stimuli including oxidative stresses $(24,25)$, cytokines (26), lipopolysaccharide $(27,28)$ and hormones $(29,30)$. In contrast, there are only a few reports documenting the effect of estrogens on the expression of the protein thiol/disulfide oxidoreductases. The content of Trx mRNA in the cervix of non-pregnant women has been reported to correlate positively with serum estradiol concentration and to increase in late pregnancy (23). HIP-70/PLC- $\alpha$, which is a member of PDI family and possesses similar redox-active cysteines, has also been shown to be induced by estradiol in rat uterus and hypothalamus (31). The present results are the first to document the estrogen-mediated induction of the protein thiol/disulfide oxidoreductases in the vascular system.

The 5'-flanking regions of the genes for these protein thiol/disulfide oxidoreductases $(32-34)$ do not appear to contain an estrogen-responsive element. The published sequence of the promoter for the PDI gene (32), however, has a consensus sequence for the antioxidant responsive element (ARE), which is activated by planar aromatic compounds like flavonoids (35). The structural similarity of estrogen and tamoxifen to flavonoids (4) may suggest the involvement of AREs in the estrogen-mediated induction of PDI, which could also explain the lack of tamoxifen inhibition in PDI induction because tamoxifen could act as an agonist for AREs of the PDI gene. Estrogen has been reported to upregulate the expression of endothelial nitric oxide synthetase (36). Increased production of NO or peroxynitrite, a metabolite of NO reacted with $\mathrm{O}_{2}^{-}$, may serve as an oxidative stress that induces the expression of the protein thiol/disulfide oxidoreductases.

In the present study, we showed that paraquatmediated lipid peroxidation in BAECs was suppressed by pretreatment with estrogen under conditions in which the expressions of all these protein thiol/disulfide oxidoreductases were enhanced. Trx and Trx reductase are known to eliminate lipid peroxides (8-11). Furthermore, Grx and PDI are reported to have dehydroascorbate reducing activity (37), which enables the recycling use of the oxidized ascorbate as an antioxidant. The antioxidant properties of these protein thiol/disulfide oxidoreductases thus suggest that the induction of these protein oxidoreductases can, at least in part, contribute to the cardioprotective antioxidant activities exhibited by estrogens.

\section{Acknowledgements}

This study was supported by a UOEH Research Grant for Promotion of Occupational Health. 


\section{References}

1 Stampfer MJ, Colditz GA, Willett WC, Manson JE, Rosner B, Speiser FE et al. Postmenopausal estrogen therapy and cardiovascular disease. Ten-year follow-up from nurses' health study. New England Journal of Medicine 199112 756-762.

2 Adams MR, Kaplan JR, Manuck SB, Koritnik DR, Parks JS, Wolfe MS et al. Inhibition of coronary artery atherosclerosis by 17-beta estradiol in ovariectomized monkeys. Lack of an effect of added progesterone. Arteriosclerosis 199010 1051-1057.

3 Krasinski K, Spyridopoulos I, Asahara T, Zee R, Isner JM \& Losordo DW. Estradiol accelerates functional endothelial recovery after arterial injury. Circulation 199795 1768-1772.

4 Wiseman H \& O'Reilly J. Molecular action of oestrogens in the prevention of cardiovascular disease. Oestrogen as antioxidant cardioprotectants. Biochemical Society Transactions 199625 $54-59$.

5 Fernando MR, Nanri H, Yoshitake S, Nagata-kuno K \& Minakami S. Thioredoxin regenerates proteins inactivated by oxidative stress in endothelial cells. European Journal of Biochemistry 1992209 917-922.

6 Yoshitake S, Nanri H, Fernando MR \& Minakami S. Possible differences in the regenerative roles played by thioltransferase and thioredoxin for oxidatively damaged proteins. Journal of Biochemistry $199411642-46$

7 Ejima K, Nanri H, Toki N, Kashimura M \& Ikeda M. Localization of thioredoxin reductase and thioredoxin in normal human placenta and their protective effect against oxidative stress. Placenta 1999 20 95-101.

8 Bjornstedt M, Hamberg M, Kumar S, Xue J \& Holmgren A. Human thioredoxin reductase directly reduces lipid hydroperoxides by NADPH and selenocysteine strongly stimulates the reaction via catalytically generated selenols. Journal of Biological Chemistry $199527011761-11764$.

9 Bjornstedt M, Xue J, Huang W, Akesson B \& Holmgren A. The thioredoxin and glutaredoxin systems are efficient electron donors to human plasma glutathione peroxidase. Journal of Biological Chemistry 1994269 29382-29384.

10 Araki M, Nanri H, Ejima K, Murasato Y, Fujiwara T, Nakashima Y \& Ikeda M. Antioxidant function of the mitochondrial protein SP-22 in the cardiovascular system. Journal of Biological Chemistry $19992742271-2278$.

11 Chae HZ, Chung SJ \& Rhee SG. Thioredoxin-dependent peroxide reductase from yeast. Journal of Biological Chemistry 1994269 27670-27678.

12 Uchida K, Szweda LI, Chae HZ \& Stadtman ER. Immunochemical detection of 4-hydroxynonenal protein adducts in oxidized hepatocytes. Proceedings of the National Academy of Sciences of the USA $1993908742-8746$.

13 Kitazono T, Takeshige K, Cragoe Jr EJ \& Minakami S. Intracellular $\mathrm{pH}$ changes of cultured bovine aortic endothelial cells in response to ATP addition. Biochemical and Biophysical Research Communications $19881521304-1309$.

14 Hillson DA, Lambert $\mathrm{N}$ \& Freedman RB. Formation and isomerization of disulfide bonds in proteins: protein disulfideisomerase. Methods in Enzymology 1984107 281-294.

15 Sata T, Takeshige K \& Minakami S. Lipid peroxidation by bovine heart submitochondrial particles stimulated by 1,1'-dimethyl4,4'-bipyridylium. Biochemical Pharmacology 198332 13-19.

16 Metzger D, Ali S, Bornert JM \& Chambon P. Characterization of the amino-terminal transcriptional activation function of the human estrogen receptor in animal and yeast. Journal of Biological Chemistry $19952709535-9542$.

17 Bar PR \& Amelink GJ. Protection against muscle damage exerted by oestrogen: hormonal or antioxidant action? Biochemical Society Transactions 199725 50-54.

18 Behl C, Widman M, Trapp T \& Holsboer F. 17-Beta estradiol protects neurons from oxidative stress-induced cell death in vivo. Biochemical and Biophysical Research Communications 1995216 $473-482$.

19 Kim YD, Chen B, Beauregard P, Kouretas P, Thomas G, Farhat MY et al. 17-Beta estradiol prevents dysfunction of canine coronary endothelium and myocardium and reperfusion arrhythmias after brief ischemia/reperfusion. Circulation 199694 2901-2908.

20 Larcot M, Leal AM, Liza M, Martin C, Martinez R \& Ruiz LM. Protective effect of estrogens and catecholestrogens against peroxidative membrane damage in vitro. Lipid 199530 141-146.

21 Oberley TD, Schultz JL \& Oberley LW. In vitro modulation of antioxidant enzyme levels in normal hamster kidney and estrogen-induced hamster kidney tumor. Free Radical Biology and Medicine 199416 741-751.

22 Tulchinsky D, Hobel CJ, Yeager E \& Marshall JR. Plasma estrone, estradiol, estriol, progesterone, and 17-hydroxyprogesterone in human pregnancy. 1. Normal pregnancy. American Journal of Obstetrics and Gynecology 1972112 1095-1100.

23 Sahlin L, Stjernholm Y, Holmgren A, Ekman G \& Eriksson H. The expression of thioredoxin mRNA is increased in the human cervix during pregnancy. Molecular Human Reproduction $199731113-$ 1117.

24 Sachi Y, Hirota K, Masatani H, Toda K, Okamoto T, Takigawa M et al. Induction of ADF/TRX by oxidative stress in keratinocytes and lymphoid cells. Immunology Letters 199544 189-193.

25 Gauntt CD, Ohira A, Honda O, Kigasawa K, Fujimoto T, Masutani $\mathrm{H}$ et al. Mitochondrial induction of adult $\mathrm{T}$ cell leukemia derived factor $(\mathrm{ADF} / \mathrm{hTx})$ after oxidative stresses in retinal pigment epithelial cells. Investigative Ophthalmology and Visual Science 199435 2916-2923.

26 Clive DR \& Greene JJ. Association of protein disulfide isomerase activity and induction of contact inhibition. Experimental Cell Research 1994214 139-144.

27 Wollman EE, Auriol L, Rimsky L, Shaw A, Jacquat JP, Wingfield P et al. Cloning and expression of a cDNA for human thioredoxin. Journal of Biological Chemistry 1988263 15506-15512.

28 Paver JL, Freedman RB \& Parkhouse RM. Induction of expression of protein disulfide-isomerase during lymphocyte maturation stimulated by bacterial lipopolysaccharide. FEBS Letters 1989 242 357-362.

29 Nieto A, Mira E \& Castano JG. Transcriptional regulation of rat liver protein disulphide-isomerase gene by insulin and in diabetes. Biochemical Journal 1990267 317-323.

30 Hansel G, Assmann V \& Kern HF. Hormonal regulation of protein disulfide isomerase and chaperone synthesis in the rat exocrine pancreas. European Journal of Cell Biology 199463 208-218.

31 Kaplitt MG, Kleopulos SP, Pfaff DW \& Mobbs CV. Estrogen increases HIP-70/PLC- $\alpha$ messenger ribonucleic acid in the rat uterus and hypothalamus. Endocrinology 1993 133 99-104.

32 Tasanen K, Oikarinen J, Kivirikko KI \& Pihlajaniemi T. Promoter of the gene for the multifunctional protein disulfide isomerase polypeptide. Functional significance of the six CCAAT boxes and other promoter elements. Journal of Biological Chemistry 1992 $26711513-11519$.

33 Kaghad M, Dessarps F, Jacquemin SH, Caput D, Fradelizi D \& Wollman EE. Genomic cloning of human thioredoxin-encoding gene: mapping of the transcription start point and analysis of the promoter. Gene $1994140273-278$.

34 Park JB \& Levine M. The human glutaredoxin gene: determination of its organization, transcription start point, and promoter analysis. Gene 1997197 189-193.

35 Rushmore TH, Morton MR \& Pickett CB. The antioxidant responsive element. Activation by oxidative stress and identification of the DNA consensus sequence required for functional activity. Journal of Biological Chemistry 1991266 11632-11639.

36 Weiner CP, Lizasoain I, Baylis SA, Knowles RG, Charles IG \& Moncada S. Induction of calcium-dependent nitric oxide synthase by sex hormones. Proceedings of the National Academy of Sciences of the USA $1994915212-5216$.

37 Wells WW, Xu DP, Yang Y \& Rocque A. Mammalian thioltransferase (glutaredoxin) and protein disulfide isomerase have dehydroascorbate reductase activity. Journal of Biological Chemistry 1990265 15361-15364.

Received 29 October 1998

Accepted 8 March 1999 